Research Article

\title{
Correlation between Soil Transmitted Helminth Infection with Nutritional Status in Elementary School at Deli Serdang Regency North Sumatera
}

\author{
Leni Andini*, Nurfadly \\ Parasitology Department, Faculty of Medicine, University of Muhammadiyah Sumatera Utara, Indonesia \\ *Corresponding author: leniandini63@gmail.com
}

\begin{abstract}
Background: The prevalence of Soil Transmitted Helminth (STH) infections in Indonesia is still high, especially in elementary school children in North Sumatra Province. STH infection is thought to cause harm to nutrient requirements due to lack of calories, causing health and nutritional conditions to decline. Purposes: To determine the relationship of STH infection with nutritional status in 105926 State Elementary School students. Method: Analytic observational with cross sectional design. Sampling uses a total sampling method, with a total sample of 87 people. Nutritional status was determined by the CDC-NCHS 2000 growth curve and the determination of the STH infection used the Kato-Katz examination method. Results: 26 samples $(29,9 \%)$ were positive and 61 samples $(70,1 \%)$ were negative for STH infections. Positive samples infected with STH have nutritional status that is dominated by moderate and good nutritional status. Conclusion: There is no correlation between STH infection and nutritional status in 105296 State Elementary School students in Percut Sei Tuan District, Deli Serdang Regency, North Sumatra.
\end{abstract}

Keywords: infection, nutritional status, soil transmitted helminth

\section{INTRODUCTION}

Soil Transmitted Helminth (STH) is a worm transmitted through soil and is one of the most common chronic infections worldwide, especially in tropical countries with low and middle income social conditions (1). The STH that most often infects human is Ascaris lumbricoides (roundworm), Trichuris trichiura (whipworm), Ancylostoma duodenale and Necator americanus (hookworm) $(2,3)$. Their infections are associated with malabsorption, growth retardation, impaired intelligence, and altered immune response $(3,4)$.

The global prevalence shows a high number of these infections, an estimated 819 million people infected with Ascaris.
Then Trichuris trichiura infected around 464.6 million people, and hookworm infections were around 438.9 million people worldwide. The highest prevalence of STH infection is found in several Asian and African countries (2).

The prevalence of STH infection in Indonesia is generally high one risk factor of STH infection is the less hygienic living environment as typically found in less developed or slum area. This is caused by overcrowding, poor sanitation, and inadequate access to clean water. The prevalence of worms varied between $2.5 \%-62 \%$. In 2017, the global burden of STH infection was estimated as 39 million DALYs, with 
hookworm contributed for 22,1 million, followed by roundworm (10,5 million), and whipworm (6,4 million). Meanwhile, based on a survey of children with worms in North Sumatra which was conducted in 2010, the results showed that the prevalence of worms in primary school children was $63 \%(5,6)$.

STH infection can decrease someone's health, nutrition, intelligence, and productivity so it causes economic disserve. STH infection causing a loss of carbohydrates and protein and also blood loss, thereby reducing the quality of human resources (7). STH in the gastrointestinal tract can interfere with the absorption of nutrients, interfere with protein absorption, and suck the blood of sufferers so that infected children experience growth problem and anemia due to malnutrition. STH also produces toxins that can cause inflammation and irritation of the intestines. From the several types of STH infections, it can be seen that there are various ways STH worms can affect the nutritional status in children (8).

Based on the results of research in Bihar, India in 2017, with the largest percentage $55 \%$ positively infected with STH. Counted 275 children infected, only $29 \%$ have normal nutritional status. The rest $71 \%$ of other children, experienced malnutrition with different levels of malnutrition (9). In addition, a study in China in 2015 where $42 \%$ were positively infected with STH with one or more than three types of STH. $42 \%$ of those infected with STH, $31 \%$ of them were underweight (7). The prevalence of STH infection cases is still believed to be high in several areas in Indonesia. STH infection were around $17 \%$ in school age children in Central Sulawesi (10). In Malang (Java island), $48 \%$ of elementary school children were infected with STH. While in Surabaya (also Java island), $36 \%$ of six to eleven years old children (typical age of elementary school children) were suffering from intestinal parasite infection (11). The fore mentioned prevalence were considered high since the target of STH elimination is to control the prevalence to be less than $10 \%$ in each regency (5). There also a study at an elementary school in Medan, North Sumatra in 2017 found that $40 \%$ of the samples were positively infected with STH with $32.5 \%$ of students were underweight (12).

Based on the infection data, both from foreign and domestic research, the researchers decided to arrange a study about the correlation between STH infection with nutritional status in 105296 State Elementary School students in Percut Sei Tuan District, Deli Serdang Regency, North Sumatra. The school was used as the research sample because the children in the school often play without paying attention to environment cleanliness, such as not using footwear when playing, not washing their hands before eating, and buying food carelessly regardless of whether the food is suitable for consumption or not. The purpose of this study was to determine the correlation between STH infection and nutritional status in elementary school students, knowing the incidence of STH infection, nutritional status of patients with STH infection, and identifying the type of STH infecting these elementary school students.

\section{METHODS}

The design of this study is cross-sectional study. This study was started from November 2019 to January 2020. The feces specimens are carried out in 105926 State Elementary School, Percut Sei Tuan, Deli 
Serdang Regency, North Sumatra, and the feces specimens were examined at the Laboratory of Parasitology in the Faculty of Medicine, Muhammadiyah University of North Sumatra.

This study use total sampling method, students from grade 1 to grade 6 were used as research samples, and those who met the inclusion criteria and the exclusion criteria were excluded. Inclusion criteria, students who are given permission by parents and parents are willing to fill out an informed consent form, students who attend and bring stool to school according to the time determined by the researcher. Exclusion criteria, taking deworming medicine in the last 1 month before the stool examination is performed, students who were not present at the time of the study.

The data collection techniques using primary data with quantitative examination. The feces specimens were examined at the Parasitology Laboratory of FK UMSU with the Kato-Katz method using Kato Solution, and primary data for anthropometric examinations using the CDC-NCHS 2000 growth curve, using data on age, weight, and height of the 105926 State Elementary School students at Percut Sei Tuan, Kabupaten Deli Serdang, North Sumatra $(13,14)$. The measurement results of CDC-NCHS 2000 growth curve can be classified: malnutrition $(<70 \%)$, underweight $(\geq 70 \%-80 \%)$, moderate $(\geq 80 \%-90 \%), \quad$ Normal $\quad(\geq 90 \%-110 \%)$, overweight $(\geq 110 \%-120 \%), \quad$ and obesity $(\geq 120 \%)(2,15)$.

Kato-Katz method was used to examine the stools. Kato-Katz was used to detect worm's eggs quantitatively. Briefly, Kato-Katz was done by putting feces as big as peanut seed on aluminum foil covered with filter wire to filter the feces. Then put the stool around $41.7 \mathrm{mg}$ in the middle of an object-glass. The specimen was then covered by a cellophane tape presoaked with malachite green and was then let sit for an hour (5). The slide was examined by parasitologist. Parasitologist reported as number of eggs per species of stool. Every examination was done twice to increase the sensitivity.

This study was conducted in two stages. The first stage was the stool collection and anthropometric data collection. On the first day, anthropometric measurements and distribution of fecal containers were carried out for students. Then the next day, the container that has been filled with feces is returned to us. The stool was immediately taken to the Laboratory of Parasitology in the Faculty of Medicine, Muhammadiyah University of North Sumatra to ensure the freshness of the stool. Second stage of the study was the fecal examination and determination of nutritional status. Data on anthropometry and STH infection were subjected to statistical analysis using the chi-square test.

Data were analyzed using Statistical Product and Service Solutions (SPSS) version 22 on the computer. This study was tested using the Chi-Square test using an alpha of 0.05 . Then the $\mathrm{P}<0.05$ is used as the limit of significance. This study has passed the ethics review of the health research ethics commission of the Medical Faculty of Muhammadiyah University of North Sumatra, Number: 317 / KEPK / FKUMSU / 2019.

\section{RESULT}

A total of 87 school children participated in the study, it was found that $26(29.9 \%)$ were STH positive and $61(70.1 \%)$ negative. Trichuris trichiura worm infection was the most common infection with $65.4 \%$, followed by Ascaris lumbricoides worm infection with $23.1 \%$, mixed infections of 
Trichuris trichiura and Ascaris lumbricoides was $11.5 \%$.

Table 1. Distribution of samples based on the type of worm that infects

\begin{tabular}{lcc}
\hline \multicolumn{1}{c}{$\begin{array}{c}\text { Type of } \\
\text { Worm }\end{array}$} & Frequency & $\begin{array}{c}\text { Percentage } \\
(\mathbf{\%})\end{array}$ \\
\hline Trichuris & 17 & 65.4 \\
trichiura & & \\
Ascaris & 6 & 23.1 \\
lumbricoides & & \\
Mix & 3 & 11.5 \\
Hookworm & 0 & 0 \\
\hline \multicolumn{1}{c}{ Total } & 26 & 100 \\
\hline
\end{tabular}

Based on the nutritional status data of the 87 samples examined, the data showed that $2.3 \%$ of all samples were malnourished, $43.7 \%$ moderately malnourished, $47.1 \%$ wellnourished, $4.6 \%$ overnutrition and $2.3 \%$ with obese.

Table 2. Sample Distribution based on Nutritional Status

\begin{tabular}{lcc}
\hline $\begin{array}{c}\text { Nutritional } \\
\text { status }\end{array}$ & Frequency & Percentage \\
\hline Malnutrition & 0 & 0 \\
Underweight & 2 & 2.3 \\
Moderate & 38 & 43.7 \\
Normal & 41 & 47.1 \\
Overweight & 4 & 4.6 \\
Obesity & 2 & 2.3 \\
\hline \multicolumn{1}{c}{ Total } & 87 & 100 \\
\hline
\end{tabular}

Then the matching process is carried out to get the significance $\mathrm{P}=0.6(\mathrm{p}>0.05)$. This shows that there is no correlation between STH infection and nutritional status in these elementary school students. Although it is not statistically related, there is a tendency, students who are positively infected with STH is more who are moderate nutritional status $(16.1 \%)$ than normal $(11.5 \%)$.
Table 3. Analysis of the correlation between STH Infection and Nutritional Status

\begin{tabular}{|c|c|c|c|c|}
\hline \multirow{2}{*}{$\begin{array}{l}\text { Nutritional } \\
\text { Status }\end{array}$} & \multicolumn{3}{|c|}{ Infection Status } & \multirow[b]{2}{*}{$\mathbf{p}$} \\
\hline & $\begin{array}{c}\text { Pos } \\
\text { N }(\%)\end{array}$ & $\begin{array}{c}\text { Neg } \\
\text { N }(\%)\end{array}$ & $\begin{array}{c}\text { Total } \\
\text { N }(\%)\end{array}$ & \\
\hline Underweight & $0(0)$ & $2(2.3)$ & $2(2.3)$ & 0.6 \\
\hline Moderate & $\begin{array}{c}14 \\
(16.1)\end{array}$ & $\begin{array}{c}24 \\
(27.6)\end{array}$ & $\begin{array}{c}38 \\
(43.7)\end{array}$ & \\
\hline Normal & $\begin{array}{c}10 \\
(11.5)\end{array}$ & $\begin{array}{c}31 \\
(35.6)\end{array}$ & $\begin{array}{c}41 \\
(47.1)\end{array}$ & \\
\hline Overweight & $\begin{array}{c}1 \\
(1.15)\end{array}$ & $\begin{array}{c}3 \\
(3.45)\end{array}$ & $\begin{array}{c}4 \\
(4.6)\end{array}$ & \\
\hline Obesity & $\begin{array}{c}1 \\
(1.15)\end{array}$ & $\begin{array}{c}1 \\
(1.15)\end{array}$ & $\begin{array}{c}2 \\
(2.3)\end{array}$ & \\
\hline & $\begin{array}{c}26 \\
(29.9)\end{array}$ & $\begin{array}{c}61 \\
(70.1)\end{array}$ & $\begin{array}{c}87 \\
(100)\end{array}$ & \\
\hline
\end{tabular}

\section{DISCUSSION}

From the previous studies, it is found that many factors affect the nutritional status of children, including eating habits, provision of foodstuffs, economic status, infectious factors, poverty, lack of availability of environmental sanitation, and lack of nutrition knowledge (16).

Based on the research data from 105296 State Elementary School students in Percut Sei Tuan District, Deli Serdang Regency, North Sumatra $47.1 \%$ of the total sample had a good nutritional status and 43.7\% had moderate nutritional status. Based on these data it can be concluded that 105926 State Elementary School had good food intake and community groups who care about family health.

From the 87 samples examined, $70.1 \%$ from 105296 State Elementary School students in Percut Sei Tuan District, Deli Serdang Regency, North Sumatra showed negative results for STH infection. The rest $29.9 \%$ are positively infected with STH, of the $29.9 \%$ of students who are positively STH infections with nutritional status dominated by moderate nutritional status and good nutrition. The nutritional status of patients with STH infection in 
105926 State Elementary School in Percut Sei Tuan District, Deli Serdang Regency, North Sumatra is counted were 14 (16.1\%) samples with moderate nutritional status, $10(11.5 \%)$ samples with good nutrition, 1 $(1.15 \%)$ sample with overnutrition and 1 $(1.15 \%)$ sample of obesity. The types of STH that infected were Trichuris trichiura (whipworm) with 17 samples (65.4\%), Ascaris lumbricoides (roundworms) 6 samples (23.1\%), and mixed infections of Trichuris trichiura and Ascaris lumbricoides were 3 samples (11.5\%).

The result of this study is also in line with the previous study in 2017 at an elementary school in Semarang which showed that there was no correlation because the number of STH infections was small and $69.1 \%$ of children had normal nutritional status (17). Likewise, the other previous study at an elementary school in Jambi founded that positively infected sample infected with STH counted 83.3\% with normal nutritional status (18). Study at an elementary school in Mandailing Natal District, $70.1 \%$ samples were infected with STH, as much as $70.6 \%$ of the samples were in good nutritional status so there were no significant correlations between STH infection with nutritional status (19). This is probably due to the low level of public awareness and knowledge of health around the study location. So that children who have a poor nutritional status or malnutrition status and who are infected with STH are not identified.

Ascariasis in children can cause digestive disorders and protein absorption, which can result in children experiencing growth problems and anemia due to malnutrition. In trichuriasis, the Trichuris trichiura worm will attach itself to the intestine by penetrating the intestinal wall, as a result, the intestinal tissue will be damaged, besides that, the worm can also produce toxins that can cause inflammation and irritation of the intestines. In hookworm infection, worms that are in the intestine will suck the patient's blood so that it will cause the sufferer to experience anemia, digestive disorders such as epigastric discomfort, constipation, or diarrhea (3).

Patients with a single STH infection or only one type of worm will complain of abdominal pain, abdominal swelling, and diarrhea. Patients infected with more than one type of STH with moderate to severe intensity of infection will experience symptoms such as single infection but with hepatomegaly and splenomegaly. STH infection is an infectious disease that has a chronic impact on nutritional status. The impact on nutritional status caused by STH infection is related to the level of infection $(20,21)$.

The risk factor for STH infection is related to age, the older the child is, the smaller the risk of the child being infected with STH. As children get older, children experience changes in play patterns, activity, and levels of hygiene or immunity (22). In this study, STH infection did not affect nutritional status. This can be caused by a mild degree of STH infection. Mild STH infection does not cause symptoms and does not affect nutritional status, while severe STH infection can cause digestive symptoms, impaired growth and physical development, so that can affect the nutritional status of children (20).

The correlation between STH infection and nutritional status has been reported repeatedly there was no correlation between these two things. In this study, there is also no evidence mentioned that STH infection is a definite cause of nutritional disorders. However, it is showing that STH infection is a factor causing impaired nutritional status 
accompanied by poor environmental sanitation conditions, insufficient food intake, low socioeconomic status (23).

STH infection can be prevented by breaking the chain of transmission, by massively administering worming medication to preventing worms in vulnerable groups to stop the spread of worm eggs from humans to the surrounding environment, improving hygiene sanitation, and cultivating clean and healthy living habits through health promotions $(5,24)$.

\section{CONCLUSION}

There were no significant correlations between STH infection and nutritional status in 105926 State Elementary School students in Percut Sei Tuan District, Deli Serdang Regency, North Sumatra. Although it is not statistically related, there is a tendency for students who are positively infected by STH to have a more moderate nutritional status than normal. Based on the statistical results of this study, STH infection did not affect nutritional status. This can be caused by a mild degree of STH infection. Mild STH infection does not cause symptoms and does not affect nutritional status, whereas severe STH infection can cause symptoms of digestive disorders, impaired growth, and physical development so that it can affect the nutritional status of children (3).

Therefore, STH infection must be prevented by breaking the chain. Transmission is the age group of toddlers and school-age children, with the provision of mass worming medication in the prevention of worms in groups susceptible to infection, to stop the spread of worm eggs from sufferers to the surrounding environment, improve sanitation hygiene, and cultivate clean and healthy living habits through health promotion $(25,26)$.

\section{ACKNOWLEDGMENT}

In preparing this article, the authors sincerely thank the university who facilitated the research, the lecturers who guided, and colleagues who helped complete this research together.

\section{CONFLICT OF INTEREST}

The author has no conflict of interest, affiliation or connection with any entity or organization that could raise biased questions in the discussion and conclusions of the manuscript.

\section{REFERENCES}

1. Hotez PJ, Alvarado M, Basáñez MG, Bolliger I, Bourne R, Boussinesq M, et al. The Global Burden of Disease Study 2010: Interpretation and Implications for the Neglected Tropical Diseases. PLoS Negl Trop Dis. 2014;

2. Pullan RL, Smith JL, Jasrasaria R, Brooker SJ. Global numbers of infection and disease burden of soil transmitted helminth infections in 2010. Parasites and Vectors. 2014;

3. Jourdan PM, Lamberton PHL, Fenwick A AD. Soil-transmitted helminth infection. Lancet. 2018;391:252-65.

4. Bethony J, Brooker S AM. Soiltransmitted helminth infections: ascariasis, trichuriasis, and hookworm. Lancet. 2006;367:152132.

5. Menteri Kesehatan Republik Indonesia. Peraturan Menteri Kesehatan Republik Indonesia Nomor 15 Tahun 2017 Tentang Penanggulangan Cacingan. Jakarta: Menteri Kesehatan Republik Indonesia; 2017.

6. Dinas Kesehatan Provinsi Sumatera 
Utara. Laporan Akuntabilitas Kinerja Instansi Pemerintah Dinas Kesehatan Provinsi Sumatera Utara Tahun 2010. Medan; 2011. p. 22-95.

7. Liu C, Luo R, Yi H, Zhang L, Li S, Bai Y, et al. Soil-transmitted helminths in Southwestern China: A cross-sectional study of links to cognitive ability, nutrition, and school performance among children. PLoS Negl Trop Dis. 2015;

8. Soedarto. Buku Ajar Parasitologi Kedokteran. Jakarta: Sagung Seto; 2011. 180-204 p.

9. Kumar S, Singh J, Kumar A. Prevalence and correlation of soil transmitted helminth infection to the degree of anemia and nutritional status among pediatric patients of age group 6-14 years in Kishanganj , Bihar, India. 2017;4(1):83-6.

10. Samarang Nurjana M SP. Soil transmitted helminth at 10 elementary school in labuan sub district donggala district central Sulawesi. J Heal Epidemiol Commun Dis. 2016;2(2):33-8.

11. Rosyidah HN PH. Prevalence of intestinal helminthiasis in children at North keputran Surabaya at 2017. J Vocat Heal Stud. 2018;1:117-20.

12. Darlan DM, Alexandra TS, Tala ZZ. Soil Transmitted Helminth Infections in Medan: a cross- sectional study of the correlation between the infection and nutritional status among elementary school children. 2017;19(2):98-103.

13. Fahmida U DD. Handbook nutritional assessment. Jakarta: SEAMEO-TROPMED RCCN, University of Indonesia; 2007.

14. Daradkeh G, Guizani N MM. Handbook for nutritional assessment through life cycle. New York: Nova Publishers, Inc; 2016.

15. Kuczmarski RJ, Ogden CL GS. 2000 CDC growth charts for the United States: Methods and development. National Center for Health Statistics. Vital Heal Stat. 2002;11(246).

16. Renanti R, Rusdji SR, Ematris S. Hubungan infeksi Soil Transmitted Helminth dengan status gizi pada murid Sekolah Dasar Negeri 29 Purus Padang. J Kesehat Andalas. 2015;4(2).

17. Kamila A. Hubungan Kecacingan Dengan Status Gizi Dan Prestasi Belajar Pada Anak Sekolah Dasar Kelas IV Dan V Di Kelurahan Bandarharjo Semarang. J Nutr Coll. 2018;7(2):77-83.

18. Fauzi R, Permana O, Fetritura Y. Hubungan kecacingan dengan status gizi siswa sekolah dasar di kecamatan pelayangan jambi. Jambi Med J. 2013;1(2):1-11.

19. Murni P, Lubis M, Fujiati I Hubungan infeksi Soil Transmitted Helminth dengan kemampuan kognitif, status nutrisi, dan prestasi belajar pada anak Sekolah Dasar di Desa Sikapas Kabupaten Mandailing Natal. Sari Pediatr. 2018;9(5).

20. Uneke C, Eze K, Oyibo P, Azu N, Ali E. Soil-Transmitted Helminth Infection In School Children In South-Eastern Nigeria: The Public Health Implication. Journal Third World Med. 2006;4(1):1-7.

21. Sayasone S, Utzinger J, Akkhavong K, Odermatt P. Acta Tropica Multiparasitism and intensity of helminth infections in relation to symptoms and nutritional status among children: A cross-sectional study in southern Lao People' $s$ 
Democratic Republic. Acta Trop. 2015;141:322-31.

22. Nurjana MA, Sumolang PPF, Chadijah S, Verdiana NN. Faktor risiko infeksi Ascaris Lumbricoides pada anak Sekolah Dasar di Kota Palu. J Vektor Penyakit. 2013;7(1):23-9.

23. L Q-C. Prevalence and intensity of interstinal parasitic infections in relation to nutritional status in Mexican school children. J R Soc Trop Med Hyg. 2004;98:653-9.

24. Worrell CM, Wiegand RE, Davis SM et al. A cross-sectional study of water, sanitation, and hygienerelated risk factors for soiltransmitted helminth infection in urban school and preschool aged children in Kibera, Nairobi. PLoS One. 2016;11(3).

25. Anderson R, Truscott J HT. The coverage and frequency of mass drug administration required to eliminate persistent transmission of soiltransmitted helminths. Philos Trans $R$ Soc L B Biol Sci. 2014;369(1645):20130435.

26. Keiser J UJ. Community-wide soiltransmitted helminth treatment is equityeffective. Lancet. 2019;393:3011-2012. 